\title{
Unjust Enrichment in Argentina: Common Law in a Civil Law System
}

The receipt of unjustified enrichment is recognized nearly everywhere as the basis for some sort of legally enforceable obligation to make restitution. The process by which concrete substance has been supplied to this vague concept is an interesting illustration of law formation. Naturally, the manner by which the notion of unjustified enrichment is transformed from a moral ideal to an effective legal principle varies from one society to another in accordance with the available institutional processes. Anglo-American lawyers are, of course, familiar with the route by which our law came to recognize unjust enrichment as an independent source of obligation through the gradual extension by fiction and analogy of certain common law and equitable remedies. Legal force was given to the principle by the fact that courts would grant relief. Recognition that the effective, substantive principle was really unjust enrichment came with the realization that the relationships involved in some of the cases for which the courts were ordering contract and trust remedies had only peripheral connections with contract or trust, if indeed they had any such connections at all. Through the common law's characteristic inductive methods of analysis, the contours of the substantive principles underlying the cases were ultimately exposed, although it cannot be said that the refinement and elaboration of these principles is complete.

The formation of the law of unjust enrichment in countries whose civil law is codified necessarily has followed a different course. Some civil codes do expressly recognize unjust enrichment as a general source of obligation, but many do not, including notably the French Code Civil. The difficulties encountered by the French courts in the process of, first, recognizing the existence of the obligation based on unjust enrichment without express code authority and then trying to keep it contained have been described by Dawson. ${ }^{1}$ The problem is that the role assigned to the judiciary in such countries tends to inhibit courts from exercising the kind of creative influence we expect from ours. Judicial decisions normally have no binding effect on later litigation between different parties, and so

Robert C. CASAD is Professor of Law, University of Kansas.

1. Dawson, Unjust Enrichment 98-107 (1951). 
the courts generally feel no strong impulse to maintain doctrinal continuity-to reconcile their views with those of other courts in similar cases. Opinions of even appellate courts frequently do not disclose all of the relevant facts and often obscure the real bases for decision.

The difficulty is compounded in Argentina by problems peculiar to Argentine federalism. The basic civil code was promulgated by the national congress, but cases arising under it are not federal cases, generally triable in the federal tribunals. The Supreme Court of the nation is constitutionally empowered to entertain appeals (cassation) from provincial courts to the end of unifying the national law, and its interpretive decisions are obligatory on lower courts. Up to now, however, this procedure has not played much of a role in unifying the law of unjust enrichment.

In this paper we will take a look at that law as reflected in the Argentine code, jurisprudencia (case law) and doctrina (learned commentaries). ${ }^{2}$ Although the principles are said to be inherited from Roman law, through the actio de in rem verso, it is essentially what we would call "common law," existing apart from the code, its authority grounded mainly on judicial rather than legislative power. The courts, however, are unfamiliar with the Common Law method, and their traditions and processes are not really adequate for the development of case law as we conceive of it.

\section{The Argentine Crvil Code}

The Spanish American republics were born at a time when codification was a dominant theme in European legal science. The French code had only recently been adopted, and its orderliness, at least as compared to the medieval Spanish law they had inherited, was very attractive to the new nations. But codification was not easy. Most of the countries were unwilling simply to copy a continental code: considerations of nationalism, and the recognition that in some respects the problems of Latin America required rules different from those of Europe, prevented it. The nations of Latin America, however, did not have a developed corps of legal scholars comparable to that of the older European nations, and so there was relatively little indigenous literature and thought from which to fashion a code. In view of these difficulties, most Latin American codes were not drafted until after the middle of the nineteenth century. The task of drawing up the codes in each country commonly fell upon one man or a small group of the leading legal authorities.

2. Translations are by the author except for the Civil Code (C.C.) passages which are the Johannini translation unless otherwise indicated. Citations to J.A. refer to Jurisprudencia Argentina; to L.L. refer to Revista Juridica La Ley; to G.F. refer to Gaceta del Foro. 
The codes that resulted from this process normally followed a pattern which the Argentine Civil Code typifies. It was prepared almost entirely by one man, Dalmacio Vélez Sársfield, whose personal prestige was so great that the code he drafted was adopted in 1869 with virtually no debate, to become effective in 1871 .

The code is a composite of provisions taken from now this and now that foreign code; of provisions deriving from leading French or German treatises, designed to reflect the developments in doctrina and jurisprudencia since the promulgation of the French civil code; and some original provisions based on special national policies. The "original" provisions in the Argentine code, however, are not for the most part the work of Vélez Sársfield: they are mostly taken from the draft or sketch (esboço) of a proposed civil code for Brazil, the work of the Brazilian jurist, Teixeira de Freitas. ${ }^{3}$ The combination of this eclectic process of formation and the absence of critical debate produced a code whose provisions did not always fit neatly together, sometimes overlapping and sometimes revealing inconsistencies.

The Civil Code of Vélez Sársfield contained no general statement of the principle of unjust enrichment. The notion of an obligation arising, not from contract or fault, but from the receipt of benefits without just cause, was still developing in Europe in the third quarter of the nineteenth century. The Prussian and Austrian codes had some rather general provisions reflecting the concept, but the French code did not treat it in any general way. Pressures were mounting, however, in French courts and French treatises to compel an expansion of the scope of certain articles of the French code by judicial construction so as to make available recovery of unjust enrichment on a fairly broad basis. ${ }^{4}$ But at the time of the Argentine codification, no one anywhere had yet succeeded in refining the doctrine of unjust enrichment to a systematic codified statement. Even the partial reform of the Argentine Civil Code in 1968 failed to incorporate any general statement of unjust enrichment, 5 although a projected reformed code promulgated in 1936 had recommended such a provision. ${ }^{8}$

3. "One Argentine writer (Lisandro Segovia, Introducción a la Exposición y Critica del Código Civil) has taken the trouble to compute Dr. Vélez Sársfield's indebtedness to the various authors and codes and proclaims the result to be: Zachariae, 78 articles; Aubry and Rau; 700; Goyena, 300; Chilean Civil Code, 170; French Civil Code, 1100; Troplong, 50; Demolombe, 52; Louisiana Code, 52; Acevedo's Uruguay Code, 27; Chabot, 18; Maynz, 13; Molitor, 13; Savigny, 4-a total of 2556 articles. The remaining 1494 articles, says Machado, (Exposición y Comentarios del Código Civil Argentino, vol. 1) were taken from Freitas' Project of Civil Code for Brazil": Eder, "Introduction" in the Johannini translation of the Argentine Code, at XXV and XXVI (1917).

4. Dawson, supra note 1 at $97-101$.

5. Ley $17,711$.

6. Proyecto de Reforma del Código Civil, arts. 852-863. The report of 
The absence of a unified statement, however, does not mean that unjust enrichment is not dealt with at all in the Argentine code. It contains a number of provisions commonly found in codes based upon Roman law, as well as some that are not so common, covering certain aspects of unjust enrichment. It also contains the codifier's footnotes, which have an authority almost as great as the text of the code itself, through which other doctrines relevant to unjust enrichment have been received into the Argentine system. A brief look at these code materials should be taken at this point.

\section{A. Gestión de Negocios (negotiorum gestio)}

The Argentine code, like most codes based upon Roman law, contains a section dealing with the rights and obligations of one who, although not an agent, has taken steps to protect or promote the affairs of another with the intention of obligating the other to pay the costs. In France and some other countries these negotiorum gestio provisions were starting points for the development, after codification, of a general doctrine permitting relief from unjust enrichment. ${ }^{7}$ In Argentine law, however, gestión de negocios is not regarded as an enrichment concept. It is treated instead as an extension of the law of agency (mandato). The obligation to reimburse the gestor (the one who "managed") extends to "all expenditures incurred by [the gestor] in connection with the management." 8 It is not limited to the amount by which the owner is enriched, except where "the business was not undertaken in a profitable manner." This phrase could have been interpreted as tying gestión de negocios generally to the principle of unjust enrichment. Apparently, however, the phrase has been applied mainly to situations where the "business" was actually some sort of commercial activity.

Art. 2302 in the chapter on Gestion de Negocios does provide for the recovery of enrichment instead of expenses as such. That article specifies that the owner will be liable only up to the amount of his "profit" in a case where the gestor, instead of intending to serve the owner, thought he was conducting his own affairs. The Argentine authorities, however, do not regard this as a case of gestión de negocios at all. The obligation of negotiorum gestio, they say, rests on the actor's intention to obligate some other party. If he thinks he is abligating no one, the concept simply is not appli-

the IV Congreso Nacional de Derecho Civil in 1970 reiterated the recommendation that a comprehensive statement of the principle be enacted. See Mosset, Enriquecimiento Sin Causa, 1970 J.A. Doctrina 444 (1970).

7. See Dawson, supra note 1 at 92-109. See also Dawson, "Negotiorum Gestio: The Altruistic Intermeddler," 74 Harv. L. Rev. 817, 1073 (1961).

8. C.C. art. 2298.

9. C.C. art. 2301. 
cable. ${ }^{10}$ It is recognized that the French call this a case of "abnormal" negotiorum gestio, but the French code lacks any provision for the recovery of beneficial expenditures generally, and so the French had to expand negotiorum gestio beyond its legitimate bounds. ${ }^{11}$ The Argentine code does contain such a general provision, described by the term empleo útil.

\section{B. Empleo Util (Beneficial Expenditure)}

The main articles concerning empleo util are 2306, 2309, and 2310. They appear in the general section entitled Gestion de Negocios, but empleo util is viewed as something entirely distinct from gestión de negocios. The text of art. 2306 specifically declares, in fact, that it is to apply only where the person making the "beneficial expenditure" was not a gestor or an agent (mandatario). Art. 2306 grants to any such person making expenditures which redound to the benefit of another "an action to recover them against the person to whose benefit they have accrued." No intent to obligate is required: the obligation on the part of the beneficiary to pay arises simply from the fact of his receiving an undeserved benefit at the expense of the actor. The language of this article does not literally limit recovery of the actor's expenditures to the amount of the other party's enrichment, but it seems never to have been suggested that it could have any other meaning. Everyone knows, from the codifier's notes, that in the empleo util provisions Vélez was trying to condense a complete chapter of Freitas' Esboço, where empleo útil was distinctly separated from gestión de negocios. Everyone understands that the action authorized by art. 2306 is the action of in rem verso for the recovery of enrichment, not the action negotiorum gestorum for the recovery of expenses. ${ }^{12}$

The code refers to recovery for "expenditures," but it is accepted that this term contemplates any sort of performance capable of pecuniary valuation, including personal services. ${ }^{13}$ The concept of em-

10. See Torino, Enriquecimiento Sin Causa 124 (1929).

11. A conflict between arts. 2297 and 2302 is apparent in relation to the extent of liability of an owner who is under a legal incapacity. Art. 2297 purports to make the incapacitated owner liable for the expenses of the gestor, while art. 2302 declares that the liability of an incapacitated owner extends only to the amount of the "profit." The probable explanation of this conflict is an oversight on the part of the codifier. Art. 2297 was apparently taken directly from Aubry and Rau, while 2303 was borrowed from Freitas' Esboço. Torino, supra n.9 at 115 , declares that art. 2302 must take precedence, since the passage taken from Aubry and Rau contemplates a system that lacks an empleo util concept basing recovery on enrichment.

12. See 2 Rezzonico, Estudio de las Obligaciones 1563 (9th ed. 1961).

13. See Rezzonico, supra n.12; and see Fernandez v. Gobierno Nacional, 1957-I (J.A.) 175 (Cam. Nac. Ap. en lo Civ. Com. Pen. Y Contenciosoadministrativo de la Cap. Fed.) (1956), and Marino v. "Firestone" (S.A.), 1953-I (J.A.) 241 (Cam. Nac. Ap. en lo Civ, de la Cap. Fed.) (1952). 
pleo util in art. 2306 is thus almost broad enough by itself to serve as a general action for unjust enrichment. But because arts. 2309 and 2310 which follow refer specifically to recovery of expenditures made in improving another's property, and because, as will be discussed more fully below, a general action of in rem verso for enrichment without cause is recognized as existing apart from the code, thus relieving some of the pressure for the expansion of empleo util to its full permissible scope, the concept of empleo util has until fairly recently been invoked mainly in cases involving improvements to property where no other code provision would allow recovery. Whenever it is applied, the basic requirements of in rem verso (described below) must be met.

\section{Pago Indebido (Unowed Payment)}

Another set of code provisions allowing relief from unjust enrichment are those dealing with unowed payment (art. $784 \mathrm{ff}$.). Two different species of unowed payment are treated: payment through error of fact or law is recoverable by art. 784, payment without cause under art. 792. The text of the former provision is generally similar to that of the French code, although the French code does not specifically cover both errors of fact and law. ${ }^{14}$ The latter provision, however, has no counterpart in the French code.

"Payment" in the Argentine civil law includes any performance of an obligation-whether it be an obligation to do or to give something. ${ }^{15}$ It is not limited to the transfer of money or other property. The performance of services, e.g., can constitute "payment." In the light of this, the potential scope of the provisions for the recovery of unowed payment appears as broad as that of empleo util. In actuality, however, these articles are rarely if ever applied except where the payment consisted in the transfer of money.

The provision for recovery of payment made through error is said to be a derivative of the Roman condictio indebiti. Few difficulties seem to arise in connection with the recovery of erroneous payment, and such as do arise are usually resolved by reference to French authorities. By contrast, the action for recovery of "payment without cause" has been troublesome. It is understood that it, like empleo util, is a partial expression of the principle of enrichment without cause, and so the elements associated with the action of in

14. To explain why he did specify both errors of fact and law, Vélez added a note to art. 784 in which he based the reason for his siding with the school of thought that favored restitution of payments made under error of law squarely on "the principle of equity that is always a principle of our law, that does not permit one to enrich himself with something belonging to another....."

15. See C.C. art. 725. 
rem verso normally are held to apply to it. Whether the "cause" element in "payment without cause" is the same as the "cause" element of the action of in rem verso is not however altogether clear. ${ }^{10}$

\section{Expenditures and Improvements on Another's Property}

Although the provisions relating to gestion de negocios and empleo util are potentially broad enough to cover most situations involving expenditures made by one person on the land of another, the Argentine code contains a large number of sections - sometimes overlapping, sometimes inconsistent-treating the matter. Such preoccupation with the problems associated with one particular form of enrichment reflects the great importance the Argentine nation, in contrast to the more developed European countries, placed upon the matter of building up its vast undeveloped land. Detailed examination of these provisions has been made elsewhere, ${ }^{17}$ and need not be repeated here.

\section{E. Benefits Received Through Nullified Juridical Acts}

The restitution of benefits received through part performance of nullified contracts or other juridical acts is specially provided for in arts. 1037-1058 of the Code. Restoration of the status quo ante is the objective of the remedy; $;^{18}$ and restitution in money or recovery in specie, even from transferees (if not bona fide purchasers for value $)^{19}$ is authorized.

\section{F. The Note to Art. 499}

The code provisions discussed above seem broad enough to cover most of the field of unjust enrichment. There is more, however. Among the codifier's notes explaining and annotating the code's articles are some in which Vélez Sársfield seemed to recognize the existence of unjust enrichment as a general source of obligation, even though it had not been expressly stated in the code. The most important of these notes is the one explaining art. 499. That article is a basic one dealing with the nature of obligations generally, providing that "there is no obligation without cause." His note explains that in this provision the code does not reject the notion of an obligation to restore "enrichment without cause." The note reads as follows: ${ }^{20}$

16. See infra text at II D.

17. See Casad, "The Mistaken Improver: A Comparative Approach," 19 Hast. L.J. 1039 (1968).

18. C.C. art. 1050.

19. C.C. art. 1051.

20. Art. 499 itself reads: "There is no obligation without cause, that is to say without being derived from one of the facts, or from one of the lawful 
The French code and other codes that have taken it as a model have confused the causes of contracts and the causes of obligations. Since the latter arise, not only from contracts and quasi-contracts that are lawful acts, but also from unlawful acts-delicts and quasi-delicts_and from family relations, their "cause" must be found in the sources (fuentes) that originate them, and not only in contracts. Ortolan, after speaking of the causes of obligations that arise from contracts, continues thusly: 'If a person has caused injury to another, be it voluntarily and with wrongful intent, or involuntarily, but through his fault, the principle of natural reason, that it is necessary to repair the evil that one has caused, tells us that here is an act productive of an obligation. If a person finds that he has through some circumstance got something that belongs to another; if he appears enriched in whatever manner to the detriment of the other, whether voluntarily or involuntarily, the principle of natural reason that no one ought to enrich himself at another's expense, and that there is an obligation to restore that with which he has enriched himself, tells us that there is in this too an act "causing" an obligation. Thus, on the one hand the consent of the parties-contracts-and on the other the innumerable events, whether they be products of the will or activity of man or of independent causes, by the effects of which one person may have harmed another through his fault, or been enriched at the expense of someone else, offer us daily innumerable and repeated causes of obligations' . . . . ${ }^{21}$

This note might be read as merely a comment concerning the sources of the obligations recognized in provisions which he did expressly incorporate in the code: i.e., as explaining why one who received a "payment without cause" (art. 792) or a "beneficial expenditure" (art. 2306) should have to repay it in the absence of agreement or fault. If he had really meant that whenever a person "through some circumstance"-any circumstance-finds himself enriched to the detriment of another he must make restitution, why did he not include a positive provision to that effect, to be enacted with the code?

Whatever his reasons, his compatriots, reading the extremely general language of that note in later years (after acceptance of the general principle of unjust enrichment by the French Cour de Cas-

or unlawful acts, of family relations, or of civil relations." The reference is to juridical "facts" (hechos juridicos) (arts. 896-922) and juridical "acts" (actos juridicos) (arts. 944 et seq.).

21. Other notes of Vélez Sársfield also recognizing the same principle are those to arts. 43,784 and 2589. 
sation and the enactment of the German Code of 1900 had made it fully respectable) have interpreted it as authority for a general obligation to restore unjust enrichment, even in situations not covered in the code. Although the note to art. 499 had been part of the legal literature since 1869 , little if any use was made of this general action until the second decade of the twentieth century. ${ }^{22}$ Modern writers, however, regard it as evidence of the great foresight of the Argentine codifier, anticipating developments that occurred later on the continent. Rebora, in discussing this note and a similar one annotating art. 728 , said that the notes put the Argentine code intermediate between the French and the German. While, as in the French code, there is no express legal text embodying the general unjust enrichment principle, the Argentine Code is more advanced by reason of these notes of the codifier "[with] which the concept that opposes all unjust enrichment appeared included among the sources of obligations, and the action of in rem verso, which the French jurisprudence recognized only in the twilight of the first century of the Civil Code of 1804, was recognized in the Argentine law since [1871]."23

The Roman law actio de in rem verso, referred to by Rebora in the passage quoted, was broadened into a generalized remedy for unjust enrichment by German scholars of the seventeenth and eighteenth centuries, and it was ultimately accepted by the French in the nineteenth. ${ }^{24}$ That Vélez Sársfield recognized it as having a place in Argentine law is clear from his notes to arts. 2297 and $2302 .{ }^{25}$ Whether the action was actually available in Argentina for situations not covered by specific code provisions before its acceptance by the French in 1892 is doubtful. It is clear, however, that the action of in rem verso is now recognized as a general remedy for enrichment without cause, covering not only actions based upon specific code provisions, but other actions as well. In any situation in which the recognized elements of the action of in rem verso are present, a remedy is available, whether or not a particular code article provides for it. Accordingly, our attention must now be directed to the elements of that action, as reflected in the Argentine doctrine and jurisprudencia.

\section{The Actio de In Rem Verso}

The objective of the action in rem verso is said to be the restor-

22. Moyano, in his classic note, "Enriquecimiento Sin Causa," 44 J.A. 838 (1933) says (at p. 848) that the principle was explicitly applied the first time in Banco de Londres y Brasil v. Gobierno Nacional, 1 J.A. 625 (1918).

23. Rebora, "Enriquecimiento Sin Causa," 50 Revista Juridica de Ciencias Sociales 566 (1923).

24. Dawson, supra n.1 at 84-107.

25. The note to art. 2297 points out the difference between recovery for the value of managing another's affairs-the action negotiorum gestio-and 
ation of the "patrimonial equilibrium" which was upset by the defendant's being enriched without cause at the expense of the plaintiff. ${ }^{26}$ The concept of the "patrimony" is rather difficult to explain precisely in terms of common law equivalents, but in this context it consists of the sum of everything of economic value that a person has at his disposal. One cannot be required to part with any of his patrimony without "cause." If one person has acquired some part of another's patrimony without such "cause," the law will not allow him to keep it. Until he restores what he has thus acquired the patrimonies are in a state of disequilibrium, a situation the law does not permit in the absence of "cause." If the equilibrium has been upset by reason of some tort or breach of contract, remedies are provided by the law through customary actions. But if the patrimonial displacement without cause cannot be corrected by such other actions, the action of in rem verso may lie.

The conditions that must exist before the action will lie have been variously stated by Argentine judges and writers, who have drawn heavily upon French sources for authority. ${ }^{27}$ In spite of the variance in phrasing, however, there would be general agreement today that the following five conditions must be met:

1) Enrichment or benefit of the defendant;

2) Impoverishment or prejudice of the plaintiff;

3) Correlation or connection between the enrichment and the impoverishment;

4) Absence of just juridical cause for the enrichment;

5) Absence of any other action founded upon law or contract to remedy the injury (usually referred to as the requirement of "subsidiary character").

\section{A. Enrichment or Benefit of the Defendant}

The doctrinal writers generally say that this element may be found any time the defendant has enjoyed an advantage, in any form whatsoever, including saving expenses, diminishing liabilities, discharging obligations, and even moral advantages, if they are ca-

recovery of the advantage actually received by the defendant_- the action in rem verso. In art. 2302 the code limits the recovery of the gestor in some specified negotiorum gestio situations to no more than the benefit received by the "owner" of the business. Vélez explains in the note that "in those cases the gestor only has the action of in rem verso."

26. Torino, supra n.10 at 195 et seq.

27. See Torino, ibid.; Rezzonico, supra n.12 at 1571-1578; 1 Fernandez de Leon, Diccionario Juridico 47 ("acción de in rem verso") (1961); Moyano, supra n.22 at 842; Note, 56 L.L. 392 (1949); Note, 10 Boletin del Instituto de Ensenanza Practica 5 (1946); Garriga, "El Enriquecimiento Sin Causa: Sus Caracters y Efectos," 1949-IV (J.A.) 679 (1949); Bonazzola, Fuentes de Obligaciones 80-81 (1955). 
pable of pecuniary evaluation. ${ }^{28}$ The decisions, however, do not consistently reflect this broad conception of the enrichment element. The "patrimonial displacement" idea often leads the courts to look for some really tangible addition to the defendant's wealth.

In Spadero v. Sijvarger, ${ }^{29}$ e.g., the parties were negotiating for the sale of a pharmacy. Agreement was never reached on some of the details, so a contract was never formed. However, plaintiff purchaser had given defendant a check for $\$ 50,000$ to guarantee his performance of the eventual contract. Defendant endorsed the check to a third party, who demanded payment and even got a judgment against plaintiff, which plaintiff had not paid at the time of the present action. Plaintiff sued defendant for restitution of payment without cause. The claim was rejected in part because there was no showing of the defendant's enrichment: the mere fact that he endorsed the check to the third party did not in itself show that defendant received anything of value for it. The decision on this point is difficult to square with the customary view that enrichment can take any form, since the defendant did receive a check which was valuable enough to enable the endorsee to get a judgment. If defendant chose to give it away, that should be his business. The court also noted, however, that plaintiff had not been impoverished since he had not paid the check or judgment. This point is even more difficult to understand since the check had produced an inescapable liability.

In another case a bank was denied recovery for enrichment without cause against the maker of a promissory note which the bank had acquired through endorsement. The maker claimed it had received no enrichment because the property the note was given to pay for never was transferred to it. Although the case was actually decided on a different ground, the court expressed agreement with the defendant's contention on the enrichment point. "Abstract" enrichment in the form of non-payment of the note was said to be an insufficient basis for an action for enrichment without cause. ${ }^{80}$ The court did not note that the defendant had acquired a right to have the property transferred-a right capable of pecuniary valuation.

Cases like these point up the basic problem described at the outset of this paper. The courts felt no very strong impulse to reconcile their views on the nature of the requisite enrichment with those of courts in other cases or with those of the doctrinal writ-

28. See Rezzonico, id. at 1572; Torino, id. at 199; Moyano, id. at 843.

29. 132 L.L. 212 (1968).

30. Banco Popular Argentino v. "Eceo" (S.A.), 12 J.A. (S.C.) 415 (Cam. Com. Cap.) (1971). The suit was brought under a special provision of the Commercial Code authorizing an action for "enrichment" under certain circumstances. This has been interpreted as embodying the elements of the action in rem verso. Gamarra v. Mitkaelian, 2 J.A. (S.C.) 457 (Cam. Civ. Cap.) (1969). 
ers. The doctrinal writers, on the other hand, feel no great need to reform their theories to reflect the decisions of the courts. The cases, after all, probably could have been decided as they were without any reference to the enrichment factor. Furthermore the facts recited may or may not have been all that were relevant to the question. In view of such uncertainty, the writers may have seen no reason to modify the basic doctrine.

The problem of establishing the time as of which the enrichment is to be determined and evaluated has also produced several variant solutions. Doctrinal purists who insist that the whole basis of the doctrine of enrichment without cause is to restore a broken patrimonial equilibrium maintain that the only proper time for this determination is the time of initiating the action. ${ }^{31}$ What may appear as an enrichment at an earlier time may disappear or diminish in magnitude in the light of later events, in which case the patrimonial equilibrium will have been wholly or partially restored without the necessity of judicial intervention. This principle is not followed strictly in the cases, however, the courts usually feeling free to determine the existence and amount of the enrichment at the time that seems appropriate for the case. For instance in De Rosa $v$. De Rosa, ${ }^{32}$ an occupying tenant without express authority from his co-tenants made some expenditures on the land which were not necessary, but were beneficial in the sense of causing an increase in the value of the land. Allowing him to recover for these expenditures from his co-tenants on the basis of enrichment without cause, the court said the time for evaluating the benefit added was the time when the work was done, not the time of the trial, where later unforeseen events had cut out some or all of the enhancement in value of the land. This liberal attitude toward an improver may be seen in many Argentine decisions, and probably reflects a very strong public policy interest in land development, which is sometimes expressly noted.

In Zurakowski $v$. Flekser ${ }^{33}$ it was the equities of the parties that led the court to look for enrichment at an earlier time. A gold ring (with a jewel) had been stolen from plaintiff. Defendant, a jeweler, acting in good faith, had purchased the ring without the jewel from the thief shortly after the theft; melted it down; and from the gold made other jewelry, which he sold. About three years later the thief was apprehended and convicted. Plaintiff chose to sue the defendant for the return of the ring (which of course was impossible) or its value. ${ }^{34}$ Since by this time the value of gold had increased

31. See e.g. Torino, supra n.10 at 205; Rezzonico, supra n.12 at 1578.

32. 1952-III (J.A.) 146 (Cam. Civ. y Com. de La Plata) (1952).

33. 1953-IV (J.A.) 246 (Cam. Nac. de Ap. de Paz de la Cap. Fed.) (1953).

34. Action based on C.C. arts. 2412, 890 and 891. 
from $\$ 8$ per gram to nearly $\$ 11$, the question of the proper time for valuation had become serious. The court of first instance, citing a recent case $\mathrm{e}^{35}$ and some French sources, held that, for an asset of increasing value, the time when the judgment should become effective was the proper time for valuation, in order to prevent prejudice to the plaintiff from the fact that the thing could not be returned to him. The court of second instance, however, disagreed. Since recovery is based on enrichment without cause, the court said, the defendant should only be liable for the difference between what he paid and the value the ring had at the time it became impossible to restore it-i.e., the time the defendant melted it down. The plaintiff must not be allowed to recover more than the profit realized by one who took an asset of increasing value in good faith; he still has his rights against the thief.

It is to be noted that the court viewed the enrichment of the defendant as being the profit received through the acquisition of the plaintiff's chattel, not the chattel itself. An American court in a quasi-contract action would have seen the enrichment in the acquisition of the chattel itself and would have allowed recovery-even as against an innocent "converter" - for the reasonable value of the chattel at the time of its acquisition. ${ }^{36}$

A common law lawyer looking at the Argentine cases dealing with the element of enrichment is likely to feel that there are some real reconciling principles at work in these cases that could be easily brought to light if the Argentines had an effective case law method.

\section{B. Impoverishment of the Plaintiff}

The element of impoverishment insisted upon as a precondition for the action in rem verso, and whose measure serves as an upper limit on recovery in any case where it is less than the amount of the defendant's enrichment, can be either a material loss or a patrimonial advantage prevented-so it is said. Services performed without remuneration are examples of the latter form. ${ }^{37}$ Doctrinal writers have taken for granted that impoverishment is a separate required

35. Grecco v. San Vincente (Cia. Microomnibus), 1948-I (J.A.) 697 (Cam. Civ. y Com de La Plata) (1948); [sub. nom. Grecco v. "Empresa San Vincente" (S.R.L.), 1948-III (J.A.) 161 (Sup. Cte. de Bs. As.) (1948) ].

36. See Restatement, Restitution $\S 128$ (comment C, ill. 3). There is an exception in those states that still limit "waiver of tort" to those cases where the converted goods have been sold by the converter; see Jones v. Hoar, 5 Pick. (22 Mass.) 285 (1827).

37. See Torino, supra n.10 at 208. Cf. Carranza v. Banco del Cordoba, 1967-II (J.A.) (prov.) 91 (Trib. Sup. Just. Cordoba) (1966) where an employee was allowed to recover in an action in rem verso for a vacation he did not take. He had been paid for his work during the vacation period, but he was impoverished in not receiving pay for not working, to which he was entitled. 
element, scoffing at such French commentators as Ripert and Teisseire who have maintained that the enrichment is the thing, apart from any notion of impoverishment. ${ }^{38}$ My survey of the cases, however, leads me to doubt the utility of treating impoverishment as a separate element. It is seldom expressly adverted to in the cases, but when it is the court's approach often is difficult to square with the broad statements of the doctrinal writers concerning the nature of the requisite impoverishment. When resort is had to the absence of impoverishment as the basis for denying recovery, there is usually a better reason for the decision, which may not even be mentioned. The court's attention may be diverted from direct consideration of more significant factors by the idea that impoverishment is an independent requirement.

The absence of impoverishment was taken as the basis for decision in Diaz v. Bodegas y Vinedos "Arizu." 39 Defendant was a wine manufacturer and plaintiff was a wine seller. A stamp tax was imposed upon wine, to be paid by manufacturers. Plaintiff had purchased wine from defendant on terms which stated the cost of the stamp tax separately. Later defendant succeeded in getting the tax declared unconsitutional and got reimbursement of the amounts it had paid. Plaintiff then sued for the share he had paid, claiming that he had made payment without cause. Recovery was denied on the ground that plaintiff had passed on the tax to the consumers who purchased from him, and therefore plaintiff was not impoverished. In so deciding the court made some economic assumptions that might be difficult to establish in fact. The facts did not indicate one way or the other whether plaintiff could not have sold the same volume of wine at retail for the same price, thus earning a greater profit if he had not had to pay the tax. If impoverishment can take the form of advantage prevented, it could probably be found here. It would seem a more reasonable assumption that plaintiff had to bear at least some of the incidence of that tax, and to that extent he must have suffered some loss as a result of having to pay it. The decision to deny recovery, however, may be sound for a different reason. To allow the plaintiff's claim in a situation where the tax officially was levied and required to be paid by the manufacturer would tend to deter the bringing of actions to challenge the constitutionality of such taxes: the person bringing the action could not be assured of keeping the reimbursement recovered. ${ }^{40}$ The contract itself between the manufacturer and the seller would seem to

38. Torino, supra n.10 at 207.

39. 1943-III (J.A.) 155 (Just. de Paz Let. Cap.) (1943).

40. This argument was considered persuasive by the court in another "tax incidence" case, Fernandez v. Palamadessi e Hijos, 70 J.A. 661 (Just. de Paz Let. Cap.) (1939), where a client sought recovery from a funeral company for taxes reimbursed to the company by the government. 
justify allowing the manufacturer to keep the amounts paid by the seller. But even if it did not, administrative necessity would seem to justify it. There is no really compelling reason for the court to become engaged in the difficult job of trying to determine the actual incidence of the tax burden in this case, for anything plaintiff would be able to get would come to him as an unexpected windfall. The defendent was enriched, but not unjustly so.

In a comparable case, Romero $v$. Municipalidad de Matanza, ${ }^{41}$ the First Civil and Commercial Appellate Chamber of La Plata found no impoverishment of a plaintiff who paid a paving assessment and then sold the land, later discovering that his lot was not a fronting lot-a narrow strip of land technically owned by the city lay between his lot and the street-and therefore that the assessment was not properly chargeable. The court found the prerequisite conditions for enrichment without cause lacking in that plaintiff had received value for his payment of the paving charge which he realized in the increased price at which he sold his land, thus plaintiff was not impoverished. This conclusion is difficult to justify. Public improvements often benefit land owners in increasing the value of their land. This benefit is a windfall for which they owe nothing unless they are legally assessable. If plaintiff had simply failed to pay the wrongful assessment, he could still have sold the land for the same price to the purchaser. It definitely appears that he has lost something: the amount he paid on the assessment. Still, it does not seem unfair that the plaintiff should have to bear some of the cost of the street. ${ }^{42}$ A different approach to the case might have yielded a more satisfactory result: If Romero had been a fronting owner, but the assessment had been invalid because of some technical defect, he probably would have been able to recover payments made only to the extent that they exceeded the amount properly assessable. Cases invoking the concept of ultimum adjutorium have held that in such situations the payments made are not fully recoverable by the owners, even though the assessment is null, since the state can easily make whatever administrative adjustments are needed to correct the legal deficiency. This being so, it would serve no good purpose to make the state give back money it could readily collect again. ${ }^{43}$ The same approach might have been possible in the Romero case. The city could have incorporated the narrow strip of land in-

41. 1945-I (J.A.) 759 (Cam. Civ. y Com. de La Plata) (1945).

42. Only a very narrow strip intervened between plaintiff's lot and the platted street-the remnant of a resurvey.

43. The rule may be different where, instead of a state levy to finance the construction of streets, a paving contract with a private company has been made. See Imaz, "Las Contribuciones de Mejoras Invalidas y El Enriquecimiento Sin Causa," 9 Boletin del Instituto de Ensenanza Practical 241 at 251 (1945). The same idea, however, was invoked in a private paving contract 
tervening between plaintiff's lot and the plotted street into the roadway itself by administrative adjustments no more difficult than those involved in reducing or balancing confiscatory assessments. Invoking this "ultimum adjutorium" notion by way of analogy could have led to a conclusion that there was a justifying cause for the municipality's retention of the payments, which would have made more sense than ruling that there was no impoverishment just because plaintiff had sold land for more than he had paid.

In Viega $v$. Gazia ${ }^{44}$ plaintiff purchased land at public sale from the defendant (estate of Gazia) for a price of $\$ 347,000$. Delivery of possession was to be made, unoccupied, within 90 days after execution of the instruments of transfer. Defendant did not make delivery until about nine months after the signing, the defendant continuing to occupy for much of that time. Plaintiff sued the estate for more than $\$ 20,000$ in damages or, in the alternative, for enrichment. The court at first instance held for the plaintiff, being of the opinion that, in spite of the fact that plaintiff had not taken possession when defendants finally did cede it and that plaintiff could show no potential sales lost because of the defendant's failure, recovery would be possible either on the contract or, otherwise, on the theory of enrichment without cause. However, the court of second instance reversed, holding that plaintiff had not proved loss, without which recovery was precluded, either on the contract or for enrichment without cause. The court apparently equated the concept of "impoverishment" for purposes of the action in rem verso with damages provable in the contract action.

The problem of unjust enrichment recovery for the occupation of land has troubled Anglo-American courts too. Although an unauthorized occupier can be held liable for mesne profits incidental to ejectment, a majority of courts have not allowed quasi-contract recovery for mere land use, following the English case Phillips $v$. Homfray. ${ }^{45}$ Mere land use was said not to constitute a benefit, since it merely saved expenses. This view is fading, however. The real explanation of the rule is to be found in the history of the common law forms of action. ${ }^{46}$ Since Argentine doctrine recognizes saving of expenses as enrichment, and since the common law forms of action

case to limit the owner's recovery of payments to the amount in excess of the increase in value of his land. Barrero y otro v. Empresa Pavimentadora "Ios Quilmes," 40 L.L. 201 (Cam. Ap. de La Plata) (1945). In the Romero case the charge was made under an assessment levy.

44. 1960-II (J.A.) 516 (Cam. Civ. Cap.) (1960).

45. 24 Ch. D. 439 (1883). See Restatement, Restitution $\S 129$ (1937). But see Raven Red Ash Coal Co. v. Ball, 185 Va. 434, 39 S.E.2d 231 (1946).

46. Nicholas, "Unjustified Enrichment in the Civil Law and Louisiana Law," 36 Tul. L. Rev. 605 (1962) at 644. Cf. Restatement, Restitution, Reporter's Notes to $\S 129$ comment A. 
never had any place in Argentine law, there is no reason why Argentine courts should have trouble fitting land use into the unjust enrichment structure. The true explanation may lie in Argentine land use policy, which encourages the useful employment of occupied land.

It is clear that the plaintiff in Viega $v$. Gazia failed to receive something she was entitled to under the terms of the sale. She was prevented from the exercise of her right of exclusive possession-a patrimonial advantage. Whether or not she chose to exercise that right and occupy the land herself is her business. Although the Argentines do not accord such exalted status to individualistic property rights as Anglo-American law does, they nevertheless recognize in the owner of land a right to exclude others from unpermitted possession, and this right is certainly capable of pecuniary valuation. And so the court's conclusion that the plaintiff suffered no impoverishment in the Viega case, as in the other cases we have noted, does not square with the conventional doctrina. The court did allude to another possible basis for decision, one based on the "subsidiary character" concept. If that "subsidiary character" requirement means that the plaintiff must have no other remedial right arising out of the events giving rise to the alleged enrichment without cause, plaintiff here would fail on that account, for she clearly has a right of action on the contract. The only thing that prevents her from realizing it is her inability to prove damages. However, as will be noted below in discussing the "subsidiary character" requirement, that concept is not normally used in the sense suggested: normally it means that the plaintiff must be unable to get recovery in any other action. Here the plaintiff was unable to get recovery in the contract action so that, under the usual view, the "subsidiary character" requirement would be met. A more satisfying approach might be to hold that there was "cause" for plaintiff's impoverishment in her failure to avail herself of a possessory action to acquire possession. Other cases have employed the cause concept in this way. ${ }^{47}$

One other impoverishment case deserves mention: Gobierno $\mathrm{Na}$ cional $v$. Wencelblat. ${ }^{48}$ The national government sued the defendant for enrichment without cause arising from the fact that defendant had obtained from the treasury at the official rates a larger quantity of foreign exchange than was necessary for its purposes. The government was trying to get the profit defendant supposedly made by selling the foreign exchange credits on the free market. Unfortunately, the government was unable to establish any actual free market sales by defendant. The court of first instance rejected the

47. See e.g. Sabin v. Vinelli, 134 L.L. 376 (C.N. Civ.) (1968).

48. 1950-II (J.A.) 31 (Cam. Fed. Cap.) (1949). 
case out of hand, saying that the state could punish defendant criminally-by fines-for exchange law violations, but that no civil obligation rested upon defendant to return benefits reaped from improper use of exchange credits. The court of second instance was not so sure: it suggested that there might be such an obligation if the government had only been able to prove some profitable sales. But the main basis of decision was that in this case no correlative impoverishment of the treasury whatsoever was shown, and so no recovery would lie. In this case impoverishment does seem quite remote, but the impoverishment would be just as remote if the defendant had made some profitable sales: that factor would only go to the question of defendant's enrichment, since the government had no right to make such sale itself.

If the enrichment were sufficiently proved, the absence of impoverishment would theoretically prevent the action. Is it sound doctrine to immunize defendant from any accountability for his use of excess exchange credits, simply because it cannot be shown that defendant's acts impoverished the state? As between the defendant and the national treasury, the latter is more deserving of any profits obtained through the use of unwarranted foreign exchange credits than the former, and therefore the former's enrichment appears unjustified. ${ }^{48}$ It was, after all, acquired in violation of a duty owed to the treasury. If impoverishment must be shown, perhaps it could be seen in the failure of the treasury to get the kind of honesty and faithfulness it was entitled to. But the Argentine emphasis on "patrimonial" displacement probably precludes this analysis, since that intangible value is essentially non-economic. A better explanation of the result might be that the whole subject of foreign exchange ought to be regarded as a matter of public law, to be regulated (if at all) by legislation or decree.

The "patrimonial equilibrium" concept and its handmaiden, the impoverishment requirement, seem to be doctrinal stumbling blocks, serving no important purpose, but standing in the way of sensible results that would otherwise be attainable in cases such as the ones we have discussed. The plaintiff should have to show some claim better than that of persons generally to the enrichment received by defendant, but no good reason has been put forth for insisting that that claim must rest on a tangible dimunution in plaintiff's wealth, which courts have insisted upon in some cases.

\section{Correlation between Enrichment and Impoverishment}

This element of the action has received relatively little attention in the cases. The writers nearly always include it among the

49. Cf. Reading v. Attorney General, [1951] A. C. 507. 
elements of the action, but their treatment of it seldom gives a very clear idea of what the element really means. The varying views of French, German, and Italian commentators, some of whom speculated at length on the nature of this relation or connection, are commonly discussed, but seldom with any attempt to relate them, except on the most abstract level, to Argentine law. ${ }^{60}$

This requirement clearly does not mean that the defendant's enrichment must have come about without the intervention of third parties. The origins of the actio de in rem verso in Roman law lay in the need for some remedy against the master or paterfamilias for contracts entered into by slaves or sons of the household. ${ }^{51}$ Its expansion into a general remedy for unjust enrichment began with the recognition that it might lie where the defendant received a benefit through the contract even of a free man non-agent. ${ }^{52}$

The defendant's enrichment must not be too remote from the plaintiff's impoverishment; there must be some such connection as we would probably describe in terms of proximate cause. The introduction of still another usage of the term "cause" into the picture, however, would probably serve more to confuse than to clarify.

One problem that has sometimes been analyzed in terms of the relation between enrichment and impoverishment is that presented when work or construction done on one piece of property has caused benefit in the form of increasing the value of land of another. In a 1944 case the Supreme Court of Buenos Aires held that a private paving contractor could not charge the fronting owners with the amount by which the paving enhanced the value of their land when the paving contract was not legally valid.53 The result might have rested on the idea that, in the case of illegal contracts, to allow the contractor to retain or recover any payments under the theory of unjust enrichment would permit him to accomplish indirectly what the law forbids. The court, however, based its decision mainly on the point that the necessary causal connection between the enrichment and the impoverishment was lacking. The enrichment was immaterial and indirect since it resulted from construction, not on the owner's land, but on public land.

This reasoning was rejected a year later by Acuña Anzorena, J.,

50. See e.g. Torino, supra n.10 at 210-221. Moyano, while insisting that a causal relation must exist, frankly admits that it is impossible to say precisely what sort of relation is required. He does say that it need not be "direct," however. See Moyano, supra n.22 at 843.

51. See Leage's Roman Private Law 374 (3rd ed. 1961). Jolowicz and Nicholas, Historical Introduction to the Study of Roman Law 257 (3rd ed. 1972).

52. See Dawson, supra n.1 at 85-86.

53. Artaza v. Cia. Platense de Electricidad Siemens Schuckert (S.A.), 1945-II (J.A.) 99 (Sup. Cte. de Bas. As.) (1944). 
in a case involving nearly identical facts. ${ }^{54}$ Dr. Acuña expressly refused to follow the decision, although it was rendered by the highest tribunal of the same province. In the first place, Acuna said, it is not necessary that the enrichment be direct or material, so long as it produces an advantage capable of being pecuniarily appraised. Moreover, in his opinion, the enrichment was direct, since no intervention by a third party was necessary to produce it. The increase in value of plaintiff's property accompanied automatically the street construction. The same could be said, of course, of an improvement constructed by a neighboring landowner producing a beneficial "fallout" to surrounding owners. Acuña said that in that case, too, the enrichment would be direct enough, but that no action in rem verso would lie because the one who improved his own land suffered no detriment whatever. Acuña did not consider the more difficult, and seemingly closer, case of the building contractor who constructed the improvement but who was unable to recover from the owner on whose land the improvement was placed; but the implications of the views he expressed suggest that he might countenance such an action if the relation between enrichment and impoverishment were the only problem.

Moyano considered a similar situation-where the contractor through bad luck or mismanagement had lost money-and concluded that the contractor could not recover anything from the surrounding owners, even though the value of their lands may have been increased. His loss did not cause the benefits obtained by the neighboring owners: their benefits were as compatible with a gain on the part of the contractor as with a loss. Thus the necessary relation between the enrichment and the impoverishment was lacking. Moyano went on to suggest, as though generalizing the same principle, that the proper relation cannot exist in any case where the enrichment precedes-in time-the impoverishment: "It cannot be said that the enrichment has been produced by the impoverishment if the impoverishment is later than the enrichment." 55 The relation or connection between enrichment and impoverishment is that of cause and effect on this view: the impoverishment must be the cause and the enrichment the effect.

One difficulty with Moyano's analysis of the "fall out" benefit problem, lies in the ambiguity of the reference to "impoverishment." $\mathrm{He}$ seems to assume the builder's impoverishment consists in the loss he incurred in performing the contract. But was not the builder "impoverished," as that term is generally used in connection with the action in rem verso, when the values in the form of material and

54. 40 L.L. 201 (Cam. Ap. de La Plata) (1945) at 203-204.

55. See Moyano, supra n.22 at 843. 
services left the 'builder's "patrimony"--i.e. when they were supplied to the construction-rather than later when he added up accounts and found he had incurred a loss?

"Fall out" enrichment deriving from improvements on another's land is not recoverable under common law notions either, although the idea that those primarily benefitted should bear a share of the cost surely underlies our laws relating to assessments for public improvements. Neither a private land owner nor his building contractor can recover from another owner any part of the enrichment cast on the latter by improvements undertaken on the former's land. This is so even if there has been a manifest benefit, because the retention of a benefit which one received without seeking it and which one had no choice about accepting is not regarded as sufficiently unjust to impose the obligation to pay for it. Argentine law, however, in which such notions as negotiorum gestio and empleo util are regular features, does not have the same reluctance as does the common law about imposing upon one an obligation to pay for a benefit one never ordered. Particularly is this true when the benefit takes the form of land improvement. Nevertheless, when the benefit is merely the automatic consequence of improvements one places on his own land, there are some pretty good reasons why the courts ought not to intervene to force others to share the cost burdens. In terms of formal doctrine, refusal to allow the action in rem verso in such cases could perhaps be explained in terms of "cause" more readily than in terms of the relation between enrichment and impoverishment. There is "cause" for the inevitable "fall out" benefit to neighbors in the owner's motive to benefit himself.

Insofar as the relation between enrichment and impoverishment is concerned, Moyano's statement, expressing it in terms of "but for" causality, is probably as good as can be found:

If the enrichment could not have been produced but for the fact that caused the impoverishment of the plaintiff, the condition must be deemed to be fulfilled. It makes no difference that the enrichment is indirect, in the sense that the value lost by the plaintiff's patrimony passses through the patrimonies of others before entering into the patrimony of the defendant. . . . 56

\section{Absence of Just Cause}

Formulation of a clear conception of this key factor is hampered by a threshold ambiguity. ${ }^{57}$ The term "cause" is a familiar jural conception in systems based upon Roman law. An elaborate body of learning has been built around it. The term has application in three

56. Ibid.

57. See infra text at n.68. 
different connections in cases where values have passed from one person to another. In one usage there must be "cause" before any exchange of values that could constitute an enrichment can take place. Cause in this sense refers to the will or intention of the parties to effect the transfer, or the provision of law that prescribes that result apart from the parties' will. An apparent transfer of property is not effective unless intended or prescribed by law, so unless there is cause in this sense (causa fuente)-the source of origin of the transfer-there is theoretically no patrimonial displacement at all and hence no basis for resort to the action in rem verso. The ineffective transfer can be remedied by other actions-e.g. the real action for reivindicación $n^{58}$ or the action of nullity. ${ }^{59}$

Another use of the term "cause" refers to the objective or purpose motivating the transfer: the donative design in the case of gratuitous transfers; the obligation the transfer was made to fulfill in the case of non-gratuitous transfers. A transfer may have a "cause" in the sense of causa fuente, i.e. in the sense that the transferor intended to make it, but lack cause in the second sense (causa fin). If the obligation the transferor thought he was discharging in making the transfer does not exist-if it lacks essential validity-there is no valid cause to legitimatize the transfer.

Finally, if the obligation motivating the transfer was a contract, cause in still a third sense is involved: the cause or consideration giving legal effect to the agreement.

The doctrinal writers have debated vigorously the question whether the "cause" factor in enrichment without cause related to causa fuente, to causa fin, or to some conception different from both. ${ }^{60}$ The discussion on the whole has been quite unedifying, since it has tended to focus attention on the artificial analytical concept of "cause," leaving the real factor of "justness" largely obscured. The reason for this preoccupation with the concept of cause lies in the fact that the Argentines assumed that the incorporation of the actio de in rem verso into their codified system brought with it all of the gloss that continental writers had placed on it, part of which was the "without just cause" limitation," which had produced plenty of confusion in Europe. Only occasionally was it suggested that Argen-

58. C.C. arts. $2758-2794$.

59. C.C. arts. 1037-1058 (nullity of juridical acts); arts. 1164-1166 (nullity of contracts of persons under incapacity); arts. 833, 857, 858-861 (nullity and rescission of "transactions"- bilateral juridical acts by which controverted obligations may be extinguished). See also Rezzonico, supra n.12 at 1049-1055.

60. See Torino, supra n.10 at 221; Rezzonico, supra n.12 at 1575. Compare Moyano, supra n.22 at 844; Note, "Requisitos de la Acción por Enriquecimiento Sin Causa," 10 Boletin del Institutio de Ensenanza Practica 5 at 8-9 (1946) and see opinion of Brunet, J., in Gresia v. Municipalidad de San Isidro, 1948II (J.A.) 624 (Sup. Cte. de Bs. As.) (1948).

61. Cf. Dawson, supra n.1 at 105. 
tine courts should seek a clearer satement of the elements of the action. ${ }^{62}$

Of the many cases that have discussed the element of "cause," in only one (so far as my research has revealed) was the choice between causa fin and causa fuente regarded as decisive. That case is Bondoni $v$. Hamberger. ${ }^{63}$ There plaintiff had contracted to sell land to defendant. Under the terms of the contract, possession was to be transferred at the time the written instrument transferring ownership was executed. ${ }^{04}$ Plaintiff was unable to make out a good title immediately, and after a bit of delay allowed defendant to enter possession anyway. Then the parties entered a new contract which, like the earlier one, recited that possession was to be delivered at the time of the execution of the writing, but this time it added that that was to take place within 60 days. Plaintiff could not make a good title in 60 more days either: he had to litigate his title with some third parties, and was unable to clear it until about 3 years later. When he finally deeded the land to defendant, he demanded an accounting for defendant's use and occupation during the period of his possession. Defendant refused to pay, and so plaintiff sued for enrichment without cause. The court of first instance found that plaintiff had voluntarily ceded possession to the defendant, and so there was "cause" for the benefit defendant received through his occupation of the land. Plaintiff appealed on the ground that the court had mistakenly used the concept of causa fuente instead of causa fin. There was causa fuente-a valid juridical act transferring occupancy -but there was no causa fin: plaintiff had no intent to benefit the defendant gratuitously for more than 60 days, and he had no obligation, contractual or legal, to permit the defendant to occupy before the execution of the writing. The court rejected plaintiff's argument that causa fin is the proper criterion. Araus Castex, J., said:

After due meditation, I reach a conclusion contrary to the meaning (urged by the plaintiff). When the ancient formulation of the principle of unjust enrichment mentions as a requirement the absence of cause, it alludes to the absence of any of those sources (fuentes) of obligations and not to the consideration for the other party's performance.

62. See Neppi, "El Concepto de Causa en el Enriquecimiento Injustificado," 50 L.L. 850 (1948). Note that the author does not use the more common term, "enriquecimeinto sin causa," in this title.

63. 1952-II (J.A.) 404 (Cam. Nac. Ap. Civ. Cap. Fed.) (1951).

64. It should be noted that under Argentine law a contract for the sale of land creates not an "obligation to give," but an "obligation to do"-an obligation to execute the written instrument that transfers the real rights. No interest in the property accrues to the purchaser-not even upon paymenttill the writing is executed. See the discussion of this in the decision of the court of second instance in Boracchia v. Lartigue, 1951-IV (J.A.) 245 (Cam. Nac. Ap. Civ. Cap. Fed.) (1951). 
After quoting from Ripert's revision of Planiol's Elementary Treatise on Civil Law, the court continued:

In the traditional expression of enrichment without cause, the word 'cause' has retained the significance it had in the condictio sine causa of Roman law. ... The word cause is taken here not in the sense of causa final, as in arts. 1108 and 1131, but in the sense of 'efficient cause':" ${ }^{65}$ it designates the juridical act as a consequence of which one person has been enabled to obtain an advantage for himself. It is always in this sense that the Romans understood the word 'cause'."6

The court did not explain what, if any, scope was left for the operation of the doctrine of enrichment without cause if it could only be invoked where there was no valid juridical act. It did go on to point out other features of the case that bolstered the decisionand which probably would have been sufficient, notably the fact that until the time the deed was executed, plaintiff had another action by which he could have dispossessed the defendant and got an accounting. And here again, it may be noted, the problem at heart is recovery for unpermitted land use, a situation for which even most Anglo-American courts refuse to allow unjust enrichment remedies.

There have been later cases in which Argentine courts have allowed an unjust enrichment recovery where this meant disregarding effective juridical acts. ${ }^{.7}$ It cannot be said that the controversy has been settled.

It will be difficult to divert attention away from these traditional "cause" concepts so long as the action bears the label "enrichment without cause." Moyano foresaw this in his classic article in 1933. In summarizing the "absence of cause" element, he said:

The use of the word "cause" in the designation of the subject has given rise to confusions, since it is one of those terms of variable and debated scope in the juridical lexicon. In

65. See Rezzonico, supra n.12 at 62-70, to the effect that causa eficiente and causa fuente are the same.

66. 1952-II (J.A.) 404 (Cam. Nac. Ap. en lo Civ. Cap.) (1951) at 406.

67. In Dallera v. Loteria de Beneficiaria Nacional y Casinos, 1960-VI (J.A.) 591 (Cam. Cov. Cap) (1960), the plaintiff had purchased and then lost a lottery ticket that bore a winning number. Under the terms of the lottery the prize could be collected only by presenting the winning ticket at a designated window, a term which had previously been upheld as a valid part of a "contract of adhesion" in D'Alfonso v. Soc. Nac. Italiana, 10 Jurisp. Civ. 31 (Cam. Ap. Civ.) (1887). Since plaintiff could not obtain the prize as such, he sued for enrichment without cause to recover, not the price of the ticket, but the amount of the prize. The recovery was allowed.

Plaintiff's loss was caused by accident; defendant's gain resulted from the accident and a contract provision. The court did not consider the fact that it was, in effect, ordering performance of the contract under circumstances which the contract expressly contemplated and in which it expressly provided that there should be no right to performance. 
this subject as in others the word is ambiguous: on the one hand the enrichment must be without "cause", while on the other it must have as a "cause" some act or sacrifice of the impoverished party. From the viewpoint of terminology, other formulas are preferable and are currently in use: unjust enrichment, unlawful enrichment, enrichmen't without right, etc. ${ }^{68}$

Moyano's attempt to describe the element of "absence of cause" consisted not in philosophical argument, but in citing four or five examples. He then concluded:

After what has been presented, it is possible to do without the diverse meanings of the word "cause" and maintain that the "lack of cause" of an enrichment must be understood as the lack of right to justify it. ${ }^{69}$

The law would probably be clear today if Moyano's suggestion had been followed more widely and more consistently.

The latest reform proposal would enact an express code provision: "When anyone without juridical cause shall be enriched unjustly to the detriment of another, he will be obligated to restore the value of the latter's impoverishment in the amount of his benefit."70 This formulation retains the reference to "cause," but does add the term "unjustly." Perhaps this would lead the courts to concentrate on "unjustness" rather than "cause" in seeking solutions to the cases -probably, on the whole, a beneficial development.

\section{E. Subsidiary Character of the Action}

This element is sometimes described as a distinct factor, ${ }^{71}$ and sometimes as a corollary of the previous one-absence of juridical cause. $^{72}$ The action in rem verso to remedy enrichment without cause is supposed to lie only where the plaintiff lacks any other action. It is not an alternative remedy. The "subsidiary character" requirement differs from the "inadequacy of the legal remedy" requirement, familiar to us in connection with equitable remedies. A "legal remedy" is "inadequate" if it is not so effective, speedy or extensive as the equitable remedy. But regardless of the superiority of the action in rem verso in these respects, if plaintiff has another

68. Moyano, supra n.22 at 844 .

69. Ibid.

70. Mossett, supra n. 6 at 448 .

71. Moyano, supra n.22 at 844 .

72. Rezzonico, supra n.12 at 1577. The relation between this element and "impoverishment" was also noted in Gresia v. Municipalidad de San Isidro, 1948-II (J.A.) 624 (Sup. Cte. de Bs. As.) (1948): the court suggested that plaintiff could not show impoverishment if he still had a valid cause of action against a third party. 
remedy for the same injury he cannot recover for enrichment without cause.

There are a few debated issues concerning this requirement. Does the subsidiary character requirement mean that if a plaintiff has a remedy against some third party, he will have no right of action for enrichment without cause against defendant? Some provincial courts have adopted this interpretation. ${ }^{73}$ The predominant view, however, seems to be that if the plaintiff has no other action against the particular defendant, it does not matter that he may have one arising out of the same facts against some third party. ${ }^{74}$ The many cases involving suits for unjust enrichment against juridical persons for torts committed by their employees or contracts concluded by employees without authority bear out this predominant view, for the plaintiff always has an independent right of action against the employee personally. The subsidiary character requirement, however, is seldom mentioned in these cases.

Another related question: is the requirement satisfied if the plaintiff can show that he cannot get any other judgment against defendant now, even though he has-or sometime had-a valid cause of action for tort or contract that is presently ineffective because of lack of necessary proof, or because of a statute of limitations, etc.? Does the plaintiff who has rendered a performance under such an agreement have a cause of action upon that contract which he cannot prove? If so, does the subsidiary character requirement prevent resort to in rem verso?

The only case found which sheds any light at all on the question is $D i$ Giovan $v$. Bago. ${ }^{75}$ There the plaintiff, who had a part-time consulting relation with defendant, had discovered a drug that was to be commercialized by defendant. Plaintiff alleged that the parties had an agreement for the payment of certain royalties to plaintiff, but could produce no written proof as required for claims over $\$ 200 .^{76}$ The court allowed recovery to plaintiff under art. $16277^{77}$ "by the principle of enrichment without cause" in spite of the absence of writing. The court apparently was treating it as though it were a case of locación de servicios (service contract) in which no price term had been agreed,

73. See Murillo v. J.I. Case Co., 37 L.L. 559 (Sup. Trib. de Santa Fe) (1944); and case discussed in Note, supra n.60 at 10 n.18 [Cam. Ap. de Bahia Blanca; 2 Diario Jur. Bs. As. 831 (1942).]

74. "It makes no difference that the impoverished one may have an action for restitution against a third party, since it is enough for the action in rem verso that no other action exists against the one enriched": Lizzi Minotti v. Dalljo, 12 J.A. (S.C.) 658 (Sup. Ct. Bs. As.) (1971) at 659 . See also opinion of court of second instance in Avila v. Coliqueo, 1946-I (J.A.) 440 (Cam. Civ. Cap.) (1945).

75. 1955-I (J.A.) 278 (Sup. Cte. de Bs. As.) (1954).

76. See C.C. arts. 1191-1193.

77. Art. 1627 allows recovery for services apart from express contract in 
but basing the obligation itself on the principle of enrichment without cause. This suggests that the "subsidiary character" requirement may be met if the plaintiff lacks an effective action-a conclusion borne out by some cases that seem to say that in rem verso will lie if the plaintiff's ordinary action is barred by prescription. ${ }^{78}$ Other cases declare, however, that the action in rem verso is not available to one who through his own fault or act has lost the right to pursue other remedies. ${ }^{70}$ No search for reconciling principles is made in the opinions.

\section{Conclusion}

This brief survey of enrichment without cause in Argentina demonstrates, I believe, the importance of some sort of effective case law method even in civil law countries. The problem is not peculiar to Argentina, of course: there is increasing awareness of it throughout the civil law world. Its significance is not limited to the subject of unjust enrichment. Indeed, the need for case law development is probably not so pressing in remedial law areas as in others where the effect on primary decision-making is more immediate. But unjust enrichment, or enrichment without cause, is generally viewed throughout Latin America as one of the four basic sources of obligations (along with tort, contract and the law), and it should merit more than haphazard treatment. Of all the Hispano-American countries, Argentina has the best developed system of reporting, publishing and indexing case decisions. If case law methodology is to gain a firm foothold in Latin America' it will probably have to start in Argentina. The subject of enrichment without cause would seem to be a fertile area for the growth of such a process.

cases where the performance of such services was the plaintiff's "profession" or "means of livelihood".

78. A 1963 law (Decreto ley 5965/63) allows the recovery of "enrichment" when a holder of a negotiable instrument cannot otherwise obtain recovery on it or on the underlying agreement. Cases applying this law indicate that the action contemplated is the familiar in rem verso, and that it will lie if other actions have lapsed due to the statute of limitations. See Gamarra v. Mitkaelian and Banco Popular Argentino v. "Eceo" (S.A.) both supra n.30.

79. See Sabin v. Vinelli, 134 L.L. 376 (C.N. Civ.) (1968); Felix v. "Colonias y Estancias El Rodeo," 1964-III (J.A.) 601 (Cam. Civ. Cap.) (1964). 